\title{
Semi-presidentialism in the Caucasus and Central Asia, edited by Robert Elgie and Sophia Moestrup [Book review]
}

\section{Gelman, Vladimir}

2019-01-02

Gelman , V 2019 , ' Semi-presidentialism in the Caucasus and Central Asia, edited by Robert Elgie and Sophia Moestrup [Book review] ' , Democratization , vol. 26 , no. 1 , pp. 168-170 . https://doi.org/10.1080/13510347.2018.1483345

http://hdl.handle.net/10138/308874

https://doi.org/10.1080/13510347.2018.1483345

cc_by_nc_nd

acceptedVersion

Downloaded from Helda, University of Helsinki institutional repository.

This is an electronic reprint of the original article.

This reprint may differ from the original in pagination and typographic detail.

Please cite the original version. 
Robert Elgie, Sophia Moestrup (eds.), Semi-Presidentialism in the Caucasus and Central Asia, Palgrave Macmillan, 2017.

Robert Elgie may be justly called "Mr. Semi-Presidentialism". No other scholar in political science has systematically analyzed this phenomenon in theoretical and comparative perspective to such a serious degree over recent decades. Elgie has further developed the research trends on varieties of presidential government previously outlined in the great debates of the 1980s and 1990s between Duverger, Linz, Lijphart, and Shugart and Carey. The new volume, co-edited by Elgie with Sophia Moestrup, focuses on semi-presidential government in five countries of post-Soviet Eurasia: Armenia, Azerbaijan, Georgia, Kazakhstan, and Kyrgyzstan. These states established various forms of semi-presidentialism after the Soviet collapse, and have demonstrated variations of political regimes and institutions and their dynamics across the time since. To what extent does semipresidentialism affect these political developments? Or, rather, should semi-presidential institutions be considered not as causes but as effects of political regime changes? Discussions in the literature are far from being exhausted, and this is why in-depth focus on regional political trajectories is always a welcome addition to large- $\mathrm{N}$ comparative institutional analysis. The editors have brought together a team of experts, who have attempted to highlight the post-Communist experience of the Caucasus and Central Asia within the framework of historical and rational choice institutionalisms. This is most probably the first book-length treatment of these issues in the region, and its trial-and-error approach results in certain advancements and certain setbacks.

In the introduction, the editors highlight several misunderstandings concerning semi-presidentialism and convincingly demonstrate that this form of government may exist in both democracies and nondemocracies, and that its impact on political regime dynamics is contradictory. While everybody agrees that institutions (including semi-presidential ones) matter for political performance, the causal mechanisms of their influence on regime dynamics are not so obvious. In the second chapter of the volume, Alexander Baturo offers a path-dependent logic of post-Soviet semi-presidentialism and traces a great degree of continuity between late-Soviet Communist leadership in the then-republics of the Soviet Union and the rise of post-Soviet "patronal presidents" (a term coined by Henry Hale). Although this historical analysis is in itself insightful, it leaves unanswered the question of the causes of the diversity of semi-presidentialism in the five counties under analysis. In essence, the country case studies demonstrate a wide range of outcomes of building semi-presidential institutions in different political contexts. Azerbaijan and Kazakhstan (the latter of which, as the editors note, barely fits the definition of semi-presidentialism) established their all-powerful presidencies in the 1990s under consolidated personalist autocracies. In contrast to this experience of authoritarian institutionbuilding, Georgia and Kyrgyzstan reduced the scope of presidential power in the wake of democratization in the 2000-2010s and empowered their parliaments and prime ministers instead. Still, their regimes are far from being full-fledged democracies, and the political institutions in these countries are rather flawed. Later, Armenia also followed a path of institutional transformation aimed at switching from a presidential-parliamentary to a premier-presidential government. This country, however, has demonstrated both the limits of authoritarian manipulations and some unintended consequences of institution-building: in April 2018, mass protests foiled long-standing president Serzh Sargsyan's attempt to secure his power as the new prime minister, and the opposition leader Nikol Pashinyan soon took the post instead. Of course, the book did not predict these developments, but they are quite indicative of the ever-changing political environment in the region; very often, statements on stability, continuity, and consolidation quickly become outdated. Overall, the major 
conclusion of the book is that the weakening of presidents is positively correlated with the weakening of authoritarian tendencies in post-Soviet Eurasia and far beyond.

The research agenda of semi-presidentialism is faced with the problem of endogenous institutional choice: constitutional changes are made by self-interested ruling elites, who tend to behave as rational power maximizers during this process. This fact places a big question mark over the independent effects of institutions on regime trajectories, and Elgie and Moestrup discuss these issues in great detail in the conclusion of the book. Unfortunately, the problem is that the very research design of the study does not imply a causal analysis based on systematic comparisons across countriesbecause of the small-N problem, the case studies serve mostly as illustrations. A possible extension of the pool of cases to other countries of post-Soviet Eurasia such as Russia or Ukraine (with their own trajectories of semi-presidentialism and regime dynamics), as well as to other regions, may open up an opportunity for the effective use of QCA techniques. However, the editors place geographical limits on their project, thus imposing analytical constraints on the research. Still, future geographical and analytical extension of the comparative studies of semi-presidentialism is not precluded, and the book under review may pave the way to new research projects on the nexus between institutionbuilding and political regime dynamics.

Vladimir Gel'man,

European University at St Petersburg and the University of Helsinki (vgelman@eu.spb.ru) 